\title{
On development of urban environment typology
}

\author{
Galina A. Osychenko \\ Department of Architectural Environment Design, Faculty of Architecture, Poltava National \\ Technical University of Jury Kondratyuk, Ukraine, e-mail: galao-08@rambler.ru
}

\begin{abstract}
Human nature, social values and structure of needs constitute the basis of the aesthetics therefore the integrated understanding of the individual and his vital activity is reflected in modern design. Relevance of this research lies in the development of an urban environment typology from the subjectivity point of view. This theme is considered in systemic integrity (human - society - humanity - biological species), which allows to identify the nature of the aesthetic measures. Subsequently, the following generalized types of environment are distinguished: naturecentric, anthropocentric, sociocentric and integrated. As a result, the research identifies the main tasks and key issues of reconstruction and humanization of the environment.
\end{abstract}

Keywords: typology, urban environment, Aesthetics, aesthetic measure.

\section{Introduction}

The Aesthetics is development of the world according to a human measuring. Alexandrov [1] identify the aesthetic value of an object through correlation of the object measure to the Human one. New towns are losing the Human measure as the latter is no longer able both to visually embrace a city as a whole and psychologically develop a sense of ownership towards its wide-scale territory. Moreover, in order to meet requirements of the large number of population the urban development is still being evaluated through the prism of its technical and economic potential, modern construction technology, return of investment and sparing use of land resources. These considerations encroach on the human uniqueness, and urban environment becomes hostile to the individual. The problem of humanization of the urban environment becomes one of the key issues in the contemporary urban planning. Arrangements and principles of the urban humanization are determined by specifics of the urban environment and its falling into a certain typological category. This emphasizes the importance and topicality of the research into the development of the urban environment typology.

\subsection{Analysis of existing publications and theoretical sources}

The architectural researches contain the wide range of the urban environment typologies. The most accepted among them is the typology by the character of functional utilization of environment (Shimko [2]; Rannev [3] and others). There are also classifications of environment based on its visual characteristics (Lynch [4]; Venturi [5]; Glazychev[6]), on patterns of human activities (Alexander et al.[7]) or behaviours (Krampen [7]; Lawson [9]; Titov [10]), morphological properties ( Krier [11]; Jencks [12]; Arapov [13]; Sharlay [14] ). Also, Iovlev [15] suggests commencing systemization of architectural space from the prism of ecology and identifies the types of spaces by composition of their material basis, environmental balance, interaction with external environment, structure and in terms of energy-informational influence on a human being. 
N. Shebek [16] suggests to lay principles of multi-levelness, social orientation, awareness and integration into the foundation of his architectural environment typology. Multi-levelness lays out the rules for dissection of the environment into separate elements. Social orientation establishes dependencies and relationships between the approaches to systemization of socio-psychological characteristics of artificial environment residents and characteristics of forming and development of their habitat. Awareness "indicates the necessity of systemic study of the morphological, phenomenological, semantic and praxeological properties of the artificial environment. The principle of integration defines rules for arranging essential features of the architectural environment aiming to present the latter as an integral whole" (Shebek [17]). N. Shebek proposed an approach to creating a typology of the architectural environment which is the most substantial, complete and has a great potential.

These classifications retain their importance in our days being extensively applied to managing scientific and design tasks. But it should be noted that the relevance, effectiveness, sphere of application of any environment typology depends on the necessity to manage a specific urban development issue, which determines the purpose and character of classification.

Our research is aimed to extend the urban environment typology from the point of view of the Aesthetic measures in an object, and to identify the key tasks of certain types of the urban environment humanization.

\subsection{Methodological foundations and methods of research}

The philosophic basis of the research lies in a dualistic model of the Aesthetics, where the Aesthetics emerges due to unity of the reality properties and human spirit, and a human is considered as a measure of the Aesthetics (Alexandrov [1]; Wilber [18,19]; and others). Here the aesthetic perception is interpreted as unity and harmony of a human and the environment. The scientific basis of the research lies in the systemic approach, aesthetics (Alexandrov [1]), the theory of urban planning composition (Jargina [20]), integral philosophy after Kenneth Earl Wilber II [18, 19], bodily approach (Aljushin and Knjazeva [21]) and others. Principal provisions of the bodily approach (endophysics) are critical in this study as they identify the human perception process as a cognitive subject and prove the dependence of object image upon the physical nature of a subject [21]. Methods of systematization, comparative analysis and synthesis have been used to address the research tasks.

\section{Philosophic foundations of the urban environment typologies development}

The theory of urban planning considers the category of the Aesthetics mainly as the Beautiful, the Beauty. The concept of the Aesthetics is extended in this research to its respective content in the contemporary aesthetics. This is a synthetic category covering the whole range of positive feelings and human emotions during interaction with the urban environment. Secondly, coming back to the definition of the Aesthetics as a human measure in a measure of object we'd like to note that the human measure has three scaling levels and, accordingly, three measures of the Aesthetics: panhuman measure, historically specific measures of a society, and an individual measure. The latter corresponds to personal aesthetic taste, a society measure is formulated as an aesthetic canon of epoch, and a panhuman measure accumulates universal values and human knowledge (Alexandrov [1]). The scaling levels of the subject of the Aesthetics also correlate with the hierarchical 
levels of urban facilities. Both humankind and an individual are the constants of history; they do not undergo principal changes in our days. The contemporary time, however, belongs to the society; its measure is the most dynamic, varied and historically justified. At the societal level the Aesthetics is inseparable from human values, and the aesthetics is combined with ethics in its reference to the universal human values - Beauty, Welfare, Truth and Benefit (Alexandrov [1]).

AQAL ("all quadrants, all levels"), the integrated model of the Kosmos by K. Wilber II $[18,19]$, allows us to determine place of a person in the system of the whole Kosmos, structure of its Worlds and substantiate the Human measure. Four worlds of a person are interrelated and interdependent: the individual internal world (I, personal, consciousness, mind), the individual external world (It, objectiveness, body and organism), and the collective inner world (We, interpersonal, culture, collective consciousness), the collective external world (They, inter-objectiveness, social systems and external manifestations of their activities). The perpetual opposition I - OTHER includes integrity and harmony of personality achieved by unity of the four worlds: I - WE-THEY-IT. According to $\mathrm{K}$. Wilber, the variety of truth-sets corresponds to each of personal worlds (harmony in its broadest sense), which allows to see the harmony of human relationships and reality, and the outside world. On the individual level it is truthfulness, on the level of relationship between an individual and society it is equitableness, on the level of material external forms it is the truth (natural objective laws) and functional consistency (Wilber [18, 19]).

The Kosmos model helps us to identify the basic conditions and measures of unity of a Person and the environment: biological measure (the body), psychological measure, cultural measure and socio-systemic measure.

The biological measure covers correspondence of the urban forms to biophysical nature of a human being: anatomical characteristics, natural bodily ability, anthropometric data, characteristics of vision, hearing, etc., motion in space as well as relevant spatial behaviour. Psychological measure covers correspondence of urban forms to cognitive abilities, mental nature of a human being, and comprehensibility of behavioural aims. Cultural measure is determined by possibility of the individual cultural identification in the urban environment, cultural connection and correlation with the social system of values. Socio-systemic measure includes potential for social identification of an individual, functional correlation between urban forms and social systems and their activities, and identification of a social content of an urban object. The last two measures of a human being are determined by the historical and social context. The cultural level of an individual belongs to all internal contents, values and beliefs which he shares within the community being part of a certain social system. The measure of a Human being therefore involves - to a certain extent - all scaling levels of the Aesthetics.

The city visualises the gist of the spatial organization of human activities. Artificial urban environment is set up in a natural environment reflecting forms of both human culture evolution and correlations between society and nature. According to the identified measure of the Aesthetics, the three essential scales and measures of urban environment development are considered aiming to humanise a city, the Human, the Society and the Nature. The environment is considered humane if it is balanced against the given scales and measures.

\section{Urban environment typology}

We suggest basing the environment typology on the following principles: 1) principle of subjectivity which determines dependence of urban environment types upon the subject's 
nature; 2) principle of conformity that mandates compliance of urban environment with the Aesthetic measures.

Domination of either Aesthetic measure identifies the following urban environment types: naturecentric, anthropocentric, sociocentric, and integrated types.

The measure of Nature prevails in the naturecentric environment when the natural environment exists as a joint ecosystem, whether it is natural or man-made by origin. The environment is characterised by the ecological cycles, and the natural system can exist without human interference or requires it occasionally. The integrated environment combines all or some aesthetic measures. Ecocentric and organic environments belong to the integrated type combining both human and nature measures. Therefore the organic environment appears when artificial and natural measures are harmoniously combined through conscious effort of the architect. Its examples can be found in the works of such representatives of the organic approach as F.L. Wright, A. Aalto, F. Hundertwasser, E. Ambasz and others.

The ecocentric artificial environment requires balance between artificial and natural environment where the principle of nature prevails. However, the natural environment requires a regular or periodic maintenance without which the natural system will diverge and occasionally degrade. The ethnic and recreational environments are types of the ecocentric one. Paraphrasing Tuan [22], it is worth noting that the ethnic environment is an "ethnic - ecological suit," shaped up by biological or ecological requirement (bio ecosystem), but at the same time developed in line with concepts of social expediency, lifestyle, morale, rules and traditions of a particular ethnic group. Like suits can reveal the bodily beauty and individual taste, the landscapes of the ethnic environment show the harmony of relations between the ethnic group and its natural surroundings. The ethnic environment is characterised by correspondence of the architecture to the natural basis, the anthropometric scale, consistency of architectural forms and methods of their spatial arrangement transmitted by a certain ethnic group through times. The recreational environment is a result of interaction between the recreational resources, structures and activities. Arranging of the recreational environment is a complex task of linking the of "man - nature - architecture" system of relationships based on integration of natural and artificial components, ecological zoning and bipolarity of environment.

In the ecocentric environment the main task of architect is maintaining the balance between the nature and artificial environment while increasing the degree of its comfort for humans. Table 1 shows possible means and methods of creating such an environment.

The bodily measure of the Human dominates the anthropocentric environment, where the individual is of a fundamental value. This is completely artificial environment characterised with human space dimensions, individual and archetypical character of architecture, and is in line with the laws of human visual perception. Architectural forms have several levels of detail, expressive texture and surface finish, expressed vertical tiers in a maximum 5-storeyed buildings. The anthropocentric environment has the following types: tactile, bodily, decorative and ornamental environment with increased building levels and scale spaces respectively. The archetypes are used in the tactile environment in their original form, and surface texture of obstructions is distinctive because of use of natural materials; micro space with personal communication distances (up to $7.5 \mathrm{~m}$ ) prevails, senses dominate in the perceived image. The scale of bodily environment is bigger than that of the tactile one (distance up to 35-50 m), it has more complicated processing of the urban wall surfaces (obstacles), which are thoroughly worked in the decorative ornamental environment transferring into the decoration. The information saturation of the decorative ornamental environment is linked with levels and detailing of facade surfaces. 
Table 1. Types of environment and means of its humanization. Ecocentric environment

\begin{tabular}{|c|c|c|}
\hline Forms of environment & Environment characteristics & Main task, essential means and tools \\
\hline 1 & 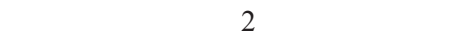 & 3 \\
\hline \multicolumn{3}{|c|}{ Ecocentric environment } \\
\hline $\begin{array}{l}\text { Balance of nature and } \\
\text { artificial environment }\end{array}$ & $\begin{array}{l}\text { Ecocyclicity, ecological integrity, scale } \\
\text { of human space }\end{array}$ & \multirow{3}{*}{$\begin{array}{l}\text { Preservation of ecological balance and } \\
\text { ethnic landscape. } \\
\text { Regulation of recreational load; } \\
\text { supporting means and protection of } \\
\text { natural components; use of eco- } \\
\text { technologies in the constructions; use } \\
\text { of methods of the "earth" and "green" } \\
\text { architecture enabling integration of } \\
\text { architecture and nature }\end{array}$} \\
\hline & & \\
\hline $\begin{array}{l}\text { Green power station Pur } \\
\text { (http://doyoulovewherey } \\
\text { noninvasive-hydroelectr }\end{array}$ & $\begin{array}{l}\text { bach, Alps. } \\
\text { oulive.com/archives/striking-yet- } \\
\text { c-power-plant-design-in-italy) }\end{array}$ & \\
\hline
\end{tabular}

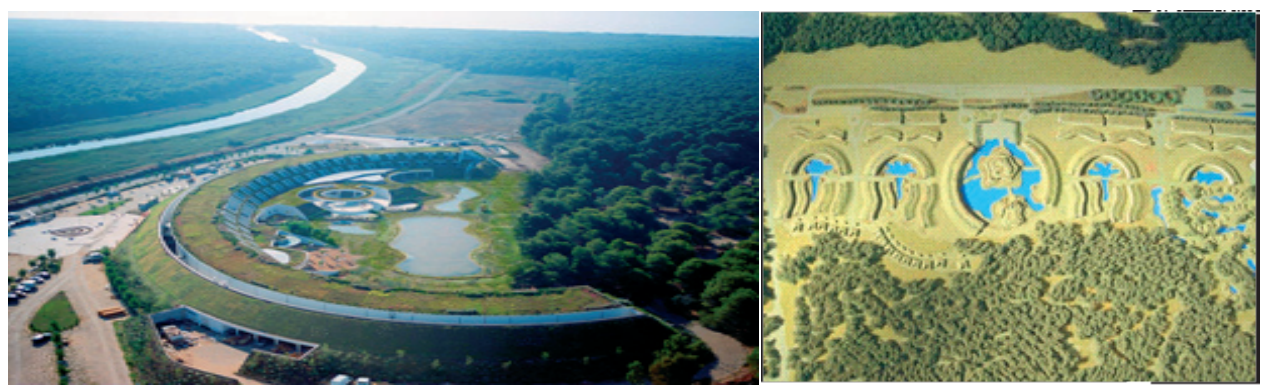

The resort Nuova Concordia, Italy (Arch. E. Ambasz) - example of "green architecture" (http://ambasz.com//portfolio/specialized/Nuova-Concordia)

The anthropocentric environment sometimes has features of the integrated one, including social aesthetic measures. First, the social status of an object, its extent and respectively social status of their owners is expressed through detailing and ornamentation of surfaces, through the high level of their development. Second, the environment has spaces for social communication, interaction between a person and society. The anthropocentric environment demonstrates the variety of historical styles and regional features. The main task of the anthropocentric environment is to preserve the historically valuable environment and adapt it to the new social requirements, modern ideas of the urban environment comfort, and reproduction of the measure of Society and the measure of Nature. Possible means, tools, and examples of adaptation are given in Table 2, together with examples of its reconstruction. 
Table 2. Types of environment and means of its humanization. Anthropocentric environment

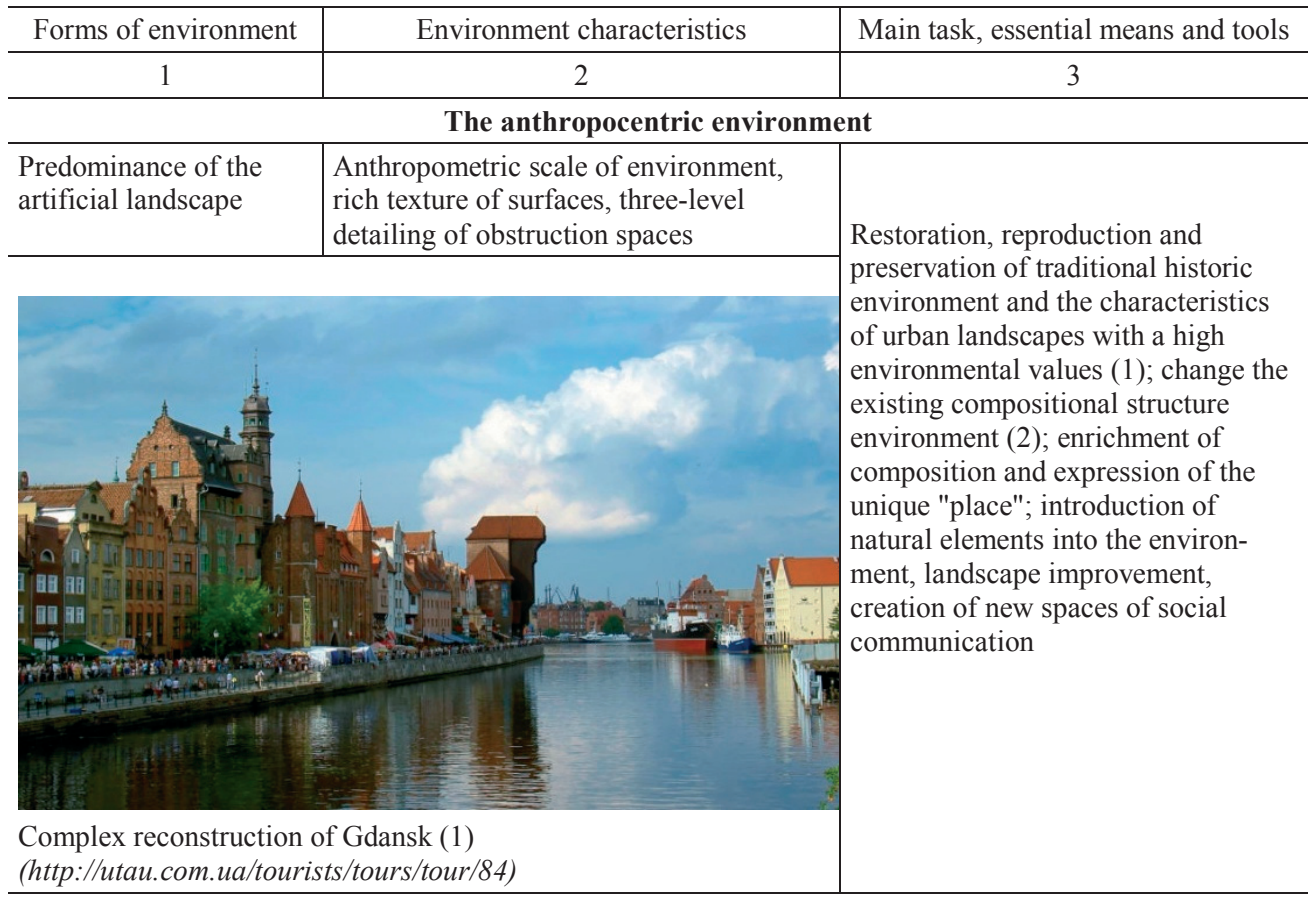
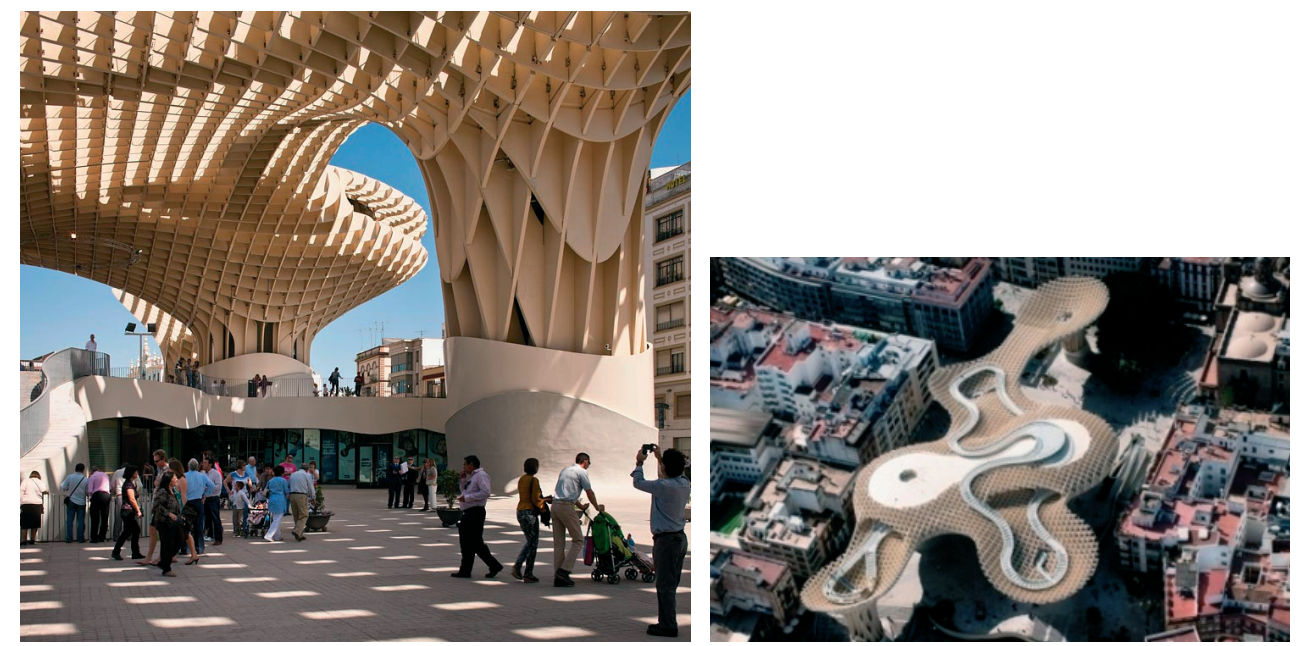

Metropol Parasol at Plaza de la Encarnación (2). Seville, Spain. Arch. J. Meyer-Hermann. 2011 http://lol54.ru/other/104633-metropol-parasol-samyjj-bolshojj-v-mire-zont-i.html)

The society measure dominates in the sociocentric environment. It depends on human activity, subject to social values, where the priority is given to the needs of society and social groups and the individual needs are sent to the back and sometimes ignored. Mezo-, macro- and mega-spaces with distances of social control and pedestrian connectivity dominate, with large-scale constructions varying from simple forms to the complex nonlinear ones. Buildings can be of different heights, styles, degrees of complexity and 
information richness, however, all of them are specified with absence of certain structural levels of surfaces details, breach of the anthropometric scale. The sociocentric environment includes the following types: functional and rational environment, modelling, hyper environment, cyber environment and technical environment. Forming of the functional and rational environment is dictated by functions, construction technologies, type design practice and large-scale redevelopment resulting in uniformity. Functional zoning becomes the principal method of its layout with majority of compositional means being ignored. The functional-rational environment still contains development of buildings up to 5 storeys which are scale-proportional to human and nature, which disappears in the modelling environment. The array of tools for compositional development is increased in the modelling environment, which start using original architectural forms, but the nature of human perception, the anthropometric scale are not considered, so buildings are viewed as a coherent composition only from the upper points of perception. Hyper environment may stand out with its distinct complex architectural forms, diversity of buildings, sophisticated silhouettes, but the height and size of buildings and spaces significantly exceed the anthropometric scale. Cyber environment is the super-modernized artificial environment, where the personal and social needs are met by use of informational, intellectual and technical means. It is characterized by the large-scale buildings and spaces, information oversaturation, active use of the underground space and presence of several vertical tiers in urban spaces. The situation in the cyber environment is characterised by constant circulation of people, vehicles, images and data. Distances are compressed, time is compacted and feeling of a "place" disappears (Boyer [23]; Soja [24]). The main shortcoming of the environment is ignoring the bodily measure of a Human, his isolation from nature which brings up the principal task of the environment humanization (Table 3), i.e. the reproduction of the measures of Human and Nature.

The technocentric environment is dominated by the technosphere, spaces are occupied with equipment, pipelines and cablings, industrial facilities, the scale of spaces and buildings ignores the human measure, organization of space depends on technological and functional processes. Since the human values in this environment fade into the background, the main task of its reconstruction is its humanization and ecologization. Examples of reconstruction of such environments are given in Table 4 .

\section{Conclusions}

According to the defined aesthetic measures we suggest the following typology of the urban environment: the naturecentric, anthropocentric, sociocentric and integrated types of environment. This typology does not conflict with the existing ones and sets priorities concerning primary means for reconstruction of urban environment. Our study identifies the principal problems, the key tasks of reconstruction and humanization for each of environment types.

Summing up the research it we would like to mention that the modern urban problems have their root in the mismatch between the identified measures and levels of the Aesthetics. The urban planning activity is aimed at finding means to balance the above named aesthetic measures.

Ultimately our research allows identifying the following project-related scientific approaches to humanisation of the urban environment: 
Table 3. Types of environment and means of its humanization. Sociocentric environment

\begin{tabular}{|c|c|c|}
\hline Forms of environment & Environment characteristics & Main task, essential means and tools \\
\hline 1 & 2 & 3 \\
\hline \multicolumn{3}{|c|}{ Sociocentric environment } \\
\hline $\begin{array}{l}\text { Predominance of } \\
\text { artificial landscape }\end{array}$ & $\begin{array}{l}\text { Macro-and mega-spaces dominate, } \\
\text { lacking degrees of the surface details of } \\
\text { obstructions. }\end{array}$ & \multirow{3}{*}{$\begin{array}{l}\text { The main task is a reproduction a of } \\
\text { Human and Nature measures. } \\
\text { Introduction of natural elements, } \\
\text { breakdown of large spaces into the } \\
\text { micro-spaces with the required level of } \\
\text { detailing, landscape improvement, } \\
\text { geoplastic of terrain, outline and colour } \\
\text { of the earth surface; invreased variety } \\
\text { of environment; formation of vertical } \\
\text { tiers; division of pedestrian and } \\
\text { transport traffic; generating of } \\
\text { pedestrian zones }\end{array}$} \\
\hline & & \\
\hline $\begin{array}{l}\text { Triumphal Square Reco } \\
\text { (http://archi.ru/news } / 51 \\
\text { alternativnyi-proekt-rek }\end{array}$ & $\begin{array}{l}\text { nstruction Project. Moscow. Russia. } 2013 . \\
\text { 97/byuro-megabudka-razrabotalo- } \\
\text { onstrukcii-triumfalnoi-ploschadi) }\end{array}$ & \\
\hline
\end{tabular}

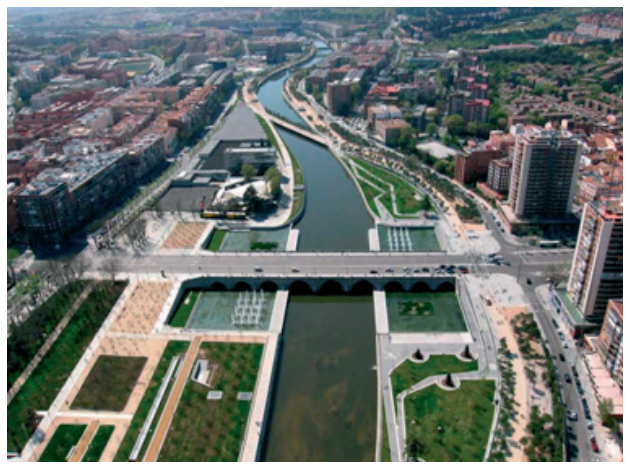

Reconstruction of the riverine areas in Madrid

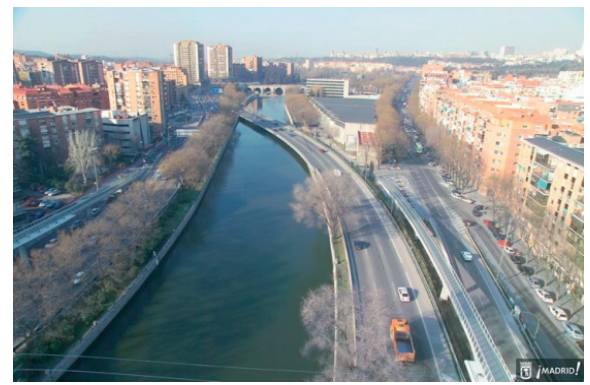

View prior to reconstruction

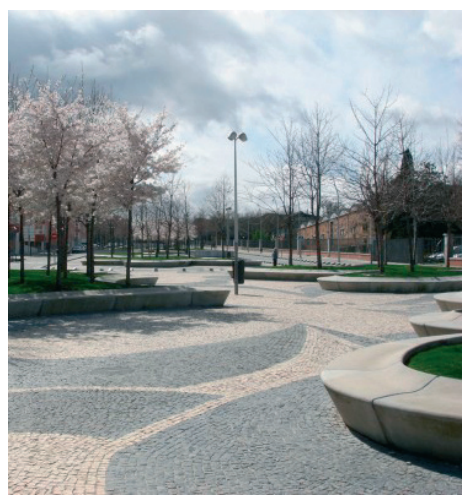

Rio Park instead of highways. Spain. 2012. «The Madrid Rio project adds more than 1,200,000 $\mathrm{m}^{2}$ of green spaces, $68,000 \mathrm{~m}^{2}$ of facilities for citizens, sport facilities, information centres and artistic installations, cultural platforms, an urban beach, ornamental fountains, 17 areas of playgrounds, kiosks, cafes, with more than 33,500 trees planted.» (http://www.eoi.es/blogs/antoniocalixtomoreno/page /2/) 


\begin{tabular}{ll|l|l|}
\hline \multicolumn{5}{c}{ Continued Table 3} \\
\hline 1 & \multicolumn{3}{c}{ Sociocentric environment } \\
\hline
\end{tabular}

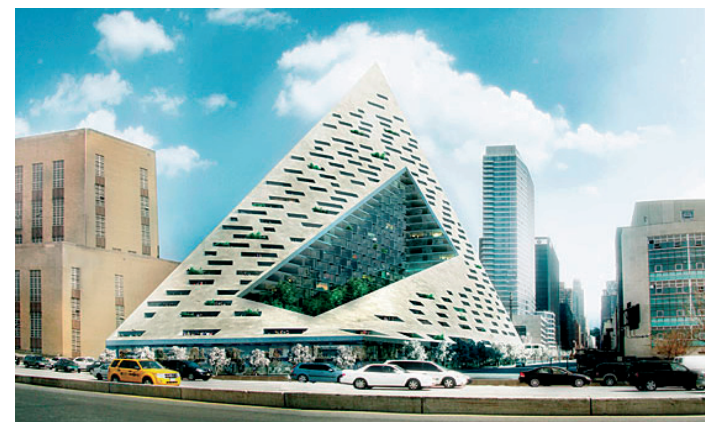

West $57^{\text {th }}$ Residential Building, New York. Arch. BIG Bjarke Ingels Group.

Project. (http://www.mymodernmet.com/profiles/blogs/ list/tag/modern-architecture)

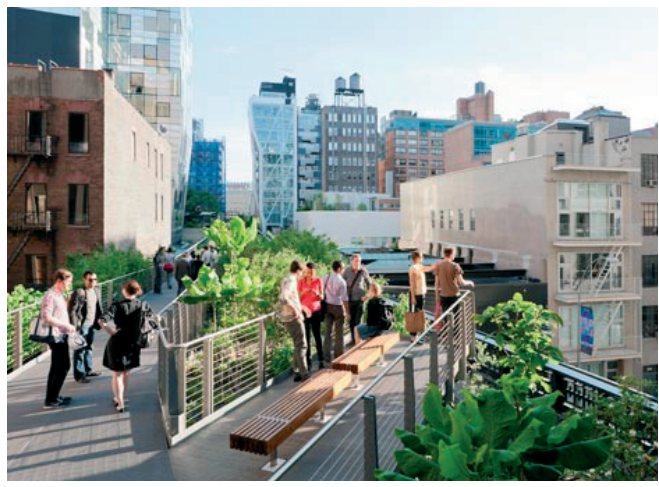

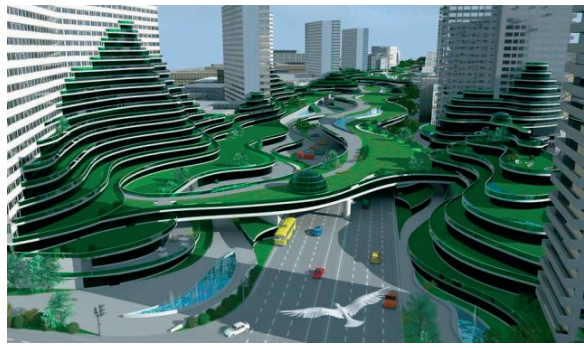

Reconstruction project Novy Arbat. Moscow. Projec. Arch. D. Onohova (http://macos.livejournal.com/875183.html)

The High Line, in collaboration with field operations, it is a new 1.5-mile long public park built on the abandoned elevated railroad stretching. New York

(http://www.dezeen.com/2011/06/13/the-high-line-section-2-by-diller-scofidio-renfro-and-james-cornerfield-operations/) 
Table 4. Types of environment and means of its humanization. Technocentric environment

\begin{tabular}{c|c|c}
\hline Forms of environment & Environment characteristics & Main task, essential means and tools \\
\hline 1 & 2 & 3 \\
\hline
\end{tabular}

\section{Technocentric environment}

Technosphere

dominates

Macro- and mega-spaces, industrial constructions, engineering and transport communications dominate, natural landscapes degrade

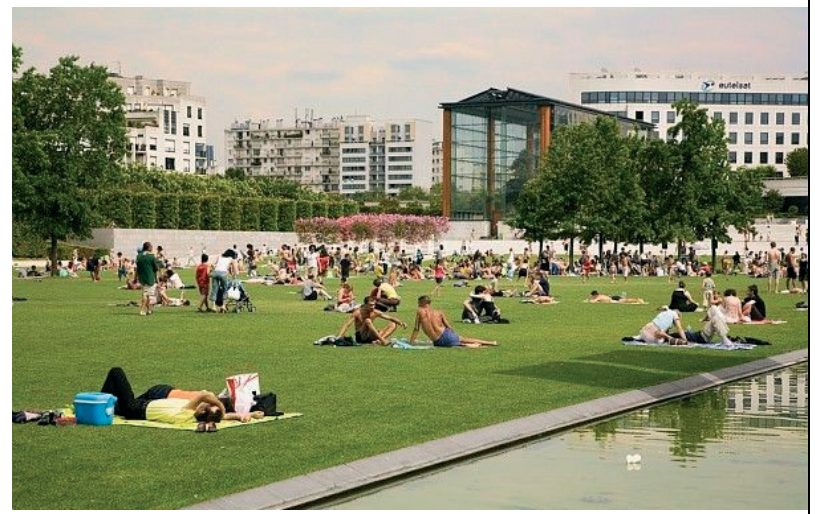

Andre-Citroen Park. Paris. Moving of the industrial facilities out of town and change of environment (http://www.guide2paris.com/information/8950/Andre-CitroenPark-Paris)
Landscapes reclamation, development regeneration, removal of industrial facilities and changes in the functional purpose of territories, use of ecotechnologies, "earth" and "green" architecture, introduction of natural elements; combination of archetypes such as "perspective" and "shelter"; more complex composition
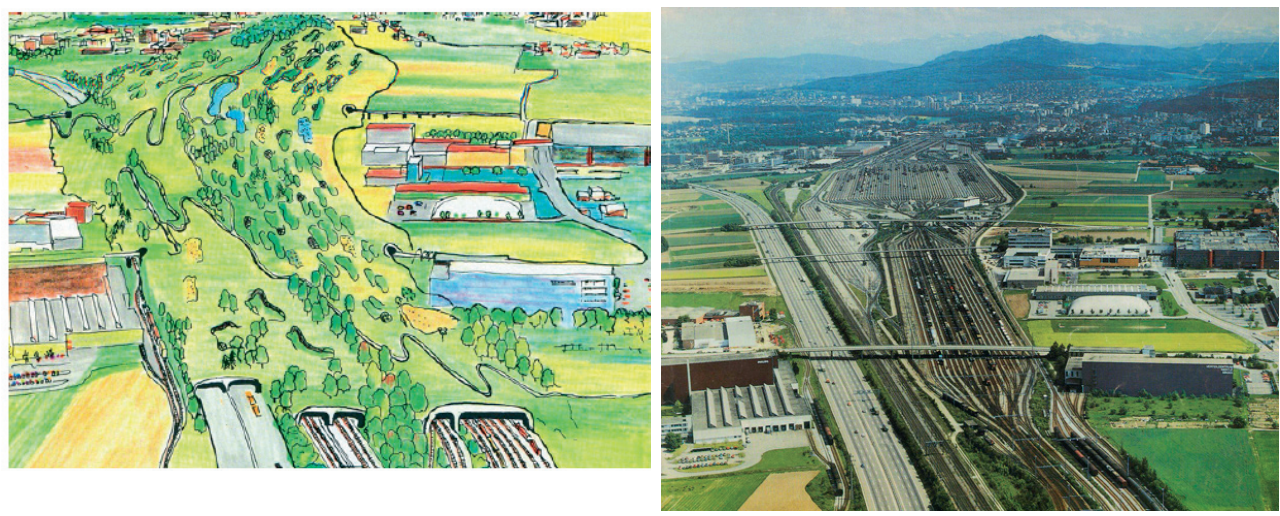

Existing condition

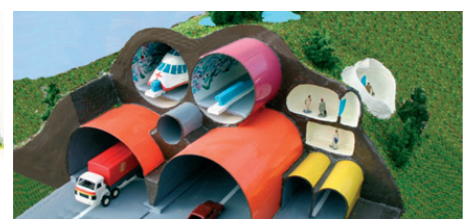

Railway rehabilitation project in Spreitenbach, Switzerland. Arch. P.Vetsh (http://www.erdhaus.ch/main.php?lang $=d e \&$ fla $=y \&$ cont $=$ start $)$ 
1) Landscape-ecological approaches: the measure of Nature is reproduced in the environment. The natural components are considered as compositional and aesthetic means. The range of directions under this approach is quite wide; it varies from aestheticization of environment by means of landscape architecture up to the deep-laid ecology and concept of the sustainable urban development.

2) Anthropo-relevant approaches: the measure of the Human is reproduced, an individual, a personality is of key value, and the primary task is to provide conditions for comprehensive physical and spiritual development of the individual. Features of human visual perception, its motion and spatial behaviour, parameters of the human ecological niche, body anthropometric characteristics become the compositional tools for design. The variety of directions is determined by the complexity of the Human as the Microcosm. Mastering of knowledge about the human in architectural theory is a permanent process which leads to emerging new means of humanization: architectural ergonomics, proxemics, physiology, video ecology, etc.

3) Socio-relevant approaches: they manage problems of a Society. These approaches are characterised by priority of social values. Their principal tasks include providing for everyday activities of a society and ethical character of the urban development.

4) Combined approaches use all the tools developed by the urban planning science and practice.

Certainly, the proposed typology of environment does not exhaust the issue of its classification but suggests approaches to its development taking into account the biological, psychological and socio-cultural nature of a human. Clarification and extension of the typology including all measures of the Aesthetics leave space for further researches.

\section{References}

1 Александров Н. Эстетика: Курс лекиий. ИАТ, Москва, 2011.

2 Шимко В. Архитектурно-дизайнерское проектирование городской средыл. Архитектура-С, Москва, 2006.

3 Раннев В. Интерьер. Высшая школа. Москва, 1987.

4 Lynch K. The Image of the City. MIT Press, Cambridge, MA, 1960.

5 Venturi R. Complexity and contradiction in architecture, published by the Museum of Modern Art. New York, 1966.

6 Глазычев В. Урбанистика. Европа, Москва, 2008.

7 Alexander C., Ishikawa S., Silverstein M., Jacobson M., Fiksdahl-King I., Angel S. A Pattern Language: Town, Building, Construction. Oxford University Press, New York, 1977.

8 Крампен М. Проксемика - секрет человеческой архитектуры. В: Семиотика пространства, ред. Барабанов А., Архитектон, Екатеринбург (1999) 285-299.

9 Lawson B. The language of space. Architectural Press, 2004.

10 Титов А. Организация архитектурной среды и поведение человека: дис. на соиск. канд. арх., Екатеринбург, 2004.

11 Krier R. Stadtraum in Theorie und Praxis. Stuttgart, 1975.

12 Jencks $\mathrm{Ch}$. The architecture of the jumping universe. A polemic: how complexity science is changing architecture and culture. Academy edition, London, Revised edition, 1997.

13 Арапов С. Методика описания морфологии городских открытых пространств. Отечественный опыт: Архитектура и градостроительство, № 2-3 (1991) 46-54.

14 Шарлай О. Морфологічні типи архітектурного середовища історичного міста на прикладі Харкова: автореф.дис. на здобуття наук.ступеня канд.арх., ХДТУБА, Харків, 1998.

15 Иовлев В. Экологические основы формирования архитектурного пространства (на примере Урала): автореферат дис. на соиск. доктора арх., МАРХИ, Москва, 2008, 17. 
16 Shebek N. Architectural socionics: possibilities and prospects of development. Innovative development trends in modern technical sciences: problems and prospects.Science editor A. Burkov. Sun Francisco, California, USA: B@M Publishing. (2013)182-183.

17 Шебек Н. Теоретичні основи гармонізації архітектурного середовища: автореферат дис. на здобуття доктора арх., КНУБА, Київ, 2013, 9.

18 Уилбер К. Око Духа. Интегральное видение для слегка свихнувшегося мира. АСТ, Москва, 2002.

19 Уилбер К. Краткая история всего. АСТ- Астрель, Москва, 2006.

20 Яргина 3. Эстетика города. Стройиздат, Москва, 1991.

21 Алюшин А., Князева Е. Эндофизический поворот в эпистемологии, или Попьттка увидеть мир изнутри. Философия и культура, №5 (2009) 80-91.

22 Tuan Y. (1983). Moral ambiguity in architecture. Landscapes 27(3) (1983) 11-17.

23 Boyer M.C. Cyber Cities. Princeton Architectural Press, New York; 2nd edition, March 1, 1996.

24 Soja Ed. Postmetropolis: Critical Studies of Cities and Regions. Basil Blackwell, Oxford, 2000. 